This article was downloaded by: ["Queen's University Libraries, Kingston"]

On: 23 April 2012, At: 13:40

Publisher: Routledge

Informa Ltd Registered in England and Wales Registered Number: 1072954 Registered

office: Mortimer House, 37-41 Mortimer Street, London W1T 3J H, UK

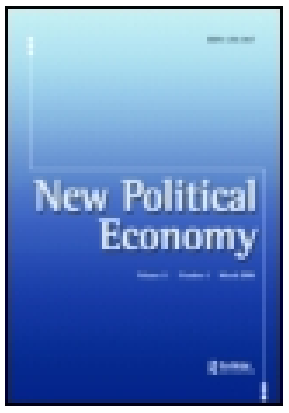

\author{
New Political Economy \\ Publication details, including instructions for authors and \\ subscription information: \\ http:// www. tandfonline.com/ loi/ cnpe20
}

\title{
Financing Social Reproduction: The Gendered Relations of Debt and Mortgage Finance in Twenty-first- century America
}

Adrienne Roberts ${ }^{a}$

a Queen's University, Political Studies, Department of Politics, Kingston, Ontario, MK7L3N6, Canada E-mail:

Available online: 10 Apr 2012

To cite this article: Adrienne Roberts (2012): Financing Social Reproduction: The Gendered Relations of Debt and Mortgage Finance in Twenty-first-century America, New Political Economy, DOI: 10. 1080/ 13563467. 2012.662951

To link to this article: http:// dx.doi.org/ 10.1080/ 13563467.2012.662951

\section{GFirst}

\section{PLEASE SCROLL DOWN FOR ARTICLE}

Full terms and conditions of use: http://www.tandfonline.com/page/terms-andconditions

This article may be used for research, teaching, and private study purposes. Any substantial or systematic reproduction, redistribution, reselling, loan, sub-licensing, systematic supply, or distribution in any form to anyone is expressly forbidden.

The publisher does not give any warranty express or implied or make any representation that the contents will be complete or accurate or up to date. The accuracy of any instructions, formulae, and drug doses should be independently verified with primary sources. The publisher shall not be liable for any loss, actions, claims, proceedings, demand, or costs or damages whatsoever or howsoever caused arising directly or indirectly in connection with or arising out of the use of this material. 


\title{
Financing Social Reproduction: The Gendered Relations of Debt and Mortgage Finance in Twenty-first-century America ${ }^{1}$
}

\author{
ADRIENNE ROBERTS
}

This article addresses a gap in the international political economy (IPE) literature on housing finance by highlighting the ways in which the deepening of mortgage debt is part of a broader attempt to individualise and (re)privatise relations of social reproduction under neoliberalism. While the extension and deepening of debt has been underpinned by policies and discourses that assume the formal equality of individuals, the attempt to erase the gendered subject in the context of ongoing inequalities in paid labour markets, in asset ownership and in the division of unpaid labour has served to reproduce various overlapping social divisions and inequalities. In linking social reproduction to financial markets, the promotion of homeownership in the US has also rendered the social reproduction of present and future generations increasingly insecure. This work contributes to feminist and other critical IPE debates by highlighting the ways in which accumulation in financial markets has been based on the perpetuation of divisions and inequalities between social classes, between men and women and along certain racial and ethnic lines. It also centralises the role of the state in conditioning these processes.

Keywords: subprime mortgages, social reproduction, feminist political economy, housing finance, debt

\section{Introduction}

Over the past three to four decades, and particularly over the past 10 years or so, Americans have fallen deeper and deeper in debt. Between 2000 and 2007, as average household incomes remained stagnant, US households doubled their outstanding debt to $\$ 13.8$ trillion, bringing the debt to GDP ratio to 98 per cent and the ratio of liabilities to disposable income to 138 per cent (Baily et al. 2009). The main driving force behind these changes was debt secured by residential real 
estate, which accounts for over 80 per cent of household liabilities, though other forms of consumer debt such as credit card debt, auto loans and student loans also rose sharply during this period. Some of the most dramatic increases in borrowing have occurred among the poor and working classes whose total outstanding debt grew by 90 per cent between 2000 and 2007 (Baily et al. 2009). The proliferation of subprime mortgages, which were given to customers with lower than average credit ratings at higher than average interest rates played an important part in fuelling this trend. Between 1998 and 2008, over 15 million subprime loans were extended, largely to low- and moderate-income Americans (CRL 2007). According to some estimates, the great majority of these loans will end in default, with perhaps as many as 10 to 13 million foreclosures taking place in the US by the time the foreclosure crisis abates (Hatzius and Marschoun 2009; Bocian et al. 2010).

The majority of critical international political economy (IPE) scholarship on subprime mortgage lending has located the dramatic proliferation of debt in transformations taking place at the macroeconomic level that have made it increasingly profitable to accumulate capital via the creation and sale of mortgage-backed securities (MBSs) and related financial derivatives (see for instance Sassen 2008, 2010; Panitch and Konings 2009; Schwartz 2009; Schwartz and Seabrooke 2009a; Harvey 2010; Wigan 2010; McNally 2011). However, in much of this work, the focus on global macroeconomic processes has obscured at least two important dimensions of subprime mortgage lending. The first relates to the ways in which the demand for subprime loans has been conditioned at the meso and micro scales by the restructuring of relations of social reproduction in ways that have made it increasingly necessary for the lower classes to rely on mortgage loans in order to meet their daily and long term needs. A central argument advanced in this article is that subprime mortgage debt should be viewed as a consequence of the 'reprivatisation of social reproduction' in the US, which involves the privatisation of risk for the majority of the population via the privatisation of health care and education services, the retrenchment of social welfare, the individualisation of old age security, the declining availability of social housing, the public subsidisation of private homeownership and other means (Bakker 2003, 2007; Bezanson and Luxton 2006). It is within this context that mortgage loans, as well as credit cards and other forms of debt, have become increasingly important individualised, privatised and market-based means of meeting daily and long-term needs. This has then reinforced the growing privatisation of social reproduction by intensifying the dependence of growing sectors of the population, particularly the working classes, single women and certain racialised minorities, on global financial markets.

There is a small but growing body of IPE and comparative political economy research that has sought to develop links between social welfare and mortgage debt, arguing that in the US and other countries following the Anglo-American model, weak welfare states have been accepted on the basis that fiscal policies are in place to help individuals accumulate private assets, particularly in the form of homes (Castles 1998; Schwartz and Seabrooke 2009a; Seabrooke 2010). Yet, despite the connection drawn in this literature between debt and 
social provisioning, virtually none of it engages with the extensive body of feminist political economy and welfare state literature documenting the gender biases that characterise different forms of social provisioning. As such, it fails to account for the ways in which deepening indebtedness has perpetuated divisions and inequalities in wealth and asset ownership along gendered lines (cf. Gill and Roberts 2011; Montgomerie and Young 2011). Addressing this second major gap in the literature on subprime lending and finance more broadly, the second main argument of this article is that the use of mortgage debt as a privatised form of social provisioning has intensified gender based inequalities. Drawing on feminist IPE and welfare state literature, it is argued that this has occurred as the result of the erasure of the gendered subject of social and economic policy and its replacement with the abstract market citizen in ways that ignore and thereby perpetuate gender-based inequalities labour markets, in asset ownership and in the division of unpaid labour (Fraser 1994; Elson and Cagatay 2000; Bakker 2003; Bezanson and Luxton 2006).

The American state has supported the deepening of mortgage debt through a combination of social and fiscal policy reforms that have limited the availability and desirability of socialised housing while simultaneously offering large and highly regressive fiscal subsidies for private homeownership. The Mortgage Interest Deduction (MID) tax benefit, for instance, is a highly regressive fiscal subsidy that privileges wealthy homeowners while at the same time helping to sustain the illusion that private homeownership is a fundamental component of participation in the US 'Ownership Society'. However, rather than equalising the playing field and 'democratising credit', mortgage loans in the US have been used as a safety net of last resort for the least well-off borrowers (Austin 2004) that ultimately serves to redistribute wealth upward, from the poor to the rich, from single women to men and from certain racial minorities to white men and their families.

The remainder of this article develops these arguments in four sections. The first section elaborates the concept of social reproduction as it is used by feminist IPE while the second section argues that the deepening of debt in general, and mortgage debt in particular, is part of a broader ongoing effort to re-privatise social reproduction under neoliberalism. The feminist IPE approach developed here challenges the tendency for critical IPE to limit its analysis to macroeconomic processes by rooting financial practices in the relations of social reproduction that are generally falsely to consider be 'extra-economic'. The third section further establishes the link between finance, social policy and social reproduction and argues that the MID tax benefit has operated as an indirect form of social policy that has subsidised private homeownership for the wealthiest segments of the population and has regressively redistributed resources in ways that privilege wealthy, white, hetero-normative nuclear families. In contrast to the subsidisation of homeownership for the wealthy through the MID, the fourth and final section looks at subprime mortgage lending, arguing that class politics overlapped with sexism and racism in order to create differences and divisions in financial markets via subprime lending as some borrowers were deemed more 'risky' than others, regardless of their actual levels of income. In so doing, it helps to demystify the idea that finance operates as a technical relation, 
devoid of social content and power relations. Subprime lending and the subsequent foreclosure crisis further highlight the insecurities and instabilities of the privatised, market-based forms of social provisioning and long-term social security.

\section{Market citizenship and social reproduction}

A foundational feminist intervention in mainstream and critical IPE debates is based on the theoretical and empirical argument that the reproduction of capitalism depends on more than the activities associated with the production and exchange of commodities. As this work has demonstrated, the reproduction of capitalism is fundamentally underpinned by the historically, culturally and geographically specific relations of social reproduction that reproduce communities, including the labour force, often without being formally recognised or compensated (Marchand and Runyan 2000; Bakker and Gill 2003; Bezanson and Luxton 2006). Though there are various competing definitions of social reproduction, it can be broadly understood as involving three main processes:

(a) biological reproduction of the species, and the conditions and social constructions of motherhood; (b) the reproduction of the labour force which involves subsistence, education and training; and (c) the reproduction and provisioning of caring needs that may be wholly privatised within families and kinship networks or socialised to some degree through state supports [i.e. via social policy]. (Bakker 2007: 541)

Drawing attention to social reproduction opens an analytical space to view capitalism as a totality, involving a wide range of social relations that are indispensable for capitalist accumulation yet which have tended to be falsely considered 'extraeconomic', or even 'natural'. Whereas the discipline of IPE tends to be characterised by a gendered division of academic labour whereby feminists theorise social reproduction and the work performed in households and non-feminist critical scholars tend to focus on trade, production and finance, exploring the articulations between these spheres yields important insights into the ways in which macroeconomic processes are intricately linked to processes taking place at the micoand meso-scales (Bakker 2007; LeBaron 2010: 890).

As feminist scholars have argued, mainstream economics is underpinned by an ontological conception of individuals as abstract and rational economic actors who make decisions based on cost-benefit calculations. These decisions are then best and most efficiently coordinated by markets, which are supposed to operate as technical, disembedded and depoliticised institutions. As such, the market is discursively and materially constructed as the best, if not the only, means of assuring the well-being of all individuals, regardless of their class, gender, race, citizenship, sexual orientation and so on. This new regime of 'market citizenship' stands in contrast to the regime of 'social citizenship' that underpinned Keynesian political and economic policies and which espoused some redistributive aims (Bakker 2003, 2007). 
The ideal of market citizenship has underpinned the discourses and policies of various US administrations that have promoted homeownership as a right for all Americans and have sought to extend this right to the working classes, minorities and women. For instance, in the 1990s, Bill Clinton's 'National Homeownership Strategy' aimed to extend homeownership to the lower classes by loosening lending standards at the government-sponsored enterprises (GSEs) Fannie Mae and Freddie Mac in ways that lowered down payments, shrank closing costs and reduced monthly obligations. The ideology of market citizenship was further promoted by George W. Bush's 'Ownership Society' initiative that aimed to integrate those who did not own homes (particularly African- and Hispanic-Americans) into the 'Ownership Society' (see also Soederberg 2007). This initiative built upon a problematic that was earlier identified by Margaret Thatcher in the UK. The problematic was that many working-class citizens were opposed to Thatcher's right-wing economic policies that were more concerned with protecting capitalist (particularly financial) accumulation and the interests of the wealthy than with improving the conditions of the working-class. The proposed solution was based on the logic that if the working-classes had a stake in the market if they had a mortgage, owned stock or had a private pension - they would come to identify themselves as owners rather than workers, thus identifying with the interests of other (larger) capitalists and veiling existing class divisions (Klein 2008). While Thatcher used the discourse of Ownership Society as a means of justifying the privatisation of the council estates (public housing) in the 1980s, Bush used it in the twenty-first century as a justification for the conversion of formerly public rental housing into private owner-occupied units (Dymski 2009: 166). Both Thatcher's programme (which encouraged the working-classes to purchase their flats in the council estates) and Bush's 'Homeownership Challenge' were thus intentionally designed to integrate previously marginalised sectors of the population into the market economy in ways that both provided new markets to exploit while simultaneously legitimising this exploitation.

While the ideology of market citizenship perpetuates an image of US society that is classless, genderless and racially and ethnically homogenous, considerable differences and inequalities continue to pervade US society. For instance, while in the US and elsewhere social and economic policies have been redesigned in ways that promote women's labour market participation (such as through the introduction of employment equity policies, tax incentives designed to encourage the market provisioning of services, the decline of the 'family wage' and welfare reforms aimed at moving single mothers into paid employment), this labour force continues to be segregated by sex and gender-based pay gaps persist (the gap in the US was estimated to be 22.4 per cent in 2006) (Orloff 2002; Bakker 2003; Brodie 2007; ILO 2010). Women also continue to make up a disproportionate number of those employed part-time, often as a result of their commitments to unpaid domestic and care work. Further, women's increased participation in the labour market has not been met with a reduction in their share of unpaid domestic labour (ILO 2009: 120, 141).

At the same time, many of the costs associated with social reproduction that were previously assumed by the state and/or employers have been shifted onto families and/or the private sector. This trend has been referred to as the 
'reprivatisation of social reproduction' and it has particularly negative implications for women who continue to perform the majority of social reproductive labour (Folbre and Nelson 2000; Bakker 2003; Bezanson and Luxton 2006). It has also heightened inequalities between women as some middle- and upperclass women are able to pay for services on the market. In many instances, this involves hiring racialised and immigrant women from the Global South to work in households, often for low wages and under highly exploitative conditions (Young 2001). Though the reprivatisation of social reproduction has been justified in official discourses by the need for states to reduce spending in the context of a 'fiscal squeeze', cuts to provisioning have tended to coincide with increases in the amount of money spent on actively surveying recipients to ensure that they do indeed constitute the 'deserving poor' and thus do not necessarily result in a reduction in spending. ${ }^{2}$

The reorganisation of social and economic policies in ways that privilege the abstract worker or 'market citizen' has entailed a partial shift away from promoting women's social and economic dependence on men toward promoting their dependence on capitalist markets (Gill and Roberts 2011). In other words, it has involved a shift away from the 'male-breadwinner' gender order, which idealised men's participation in the labour market and women's economic dependence on men, toward a new 'dual-earner' model that assumes men and women's equal participation in paid labour markets (Elson and Çagatay 2000). In failing to recognise gender-based inequalities in paid and unpaid labour, the compulsion for women to depend on markets for forms of social provisioning exacerbates existing inequalities. Ann Orloff (2002: 22) explains the trend as such:
Existing social provision for workers, developed with men's pat- terns of work and care in mind, is often inadequate for women workers, particularly when they have caregiving responsibilities that limit their capacities to be employed. Today's developed countries are committed to the standard of equal treatment of men and women within social security systems (Brocas et al. 1990). Discrimination based on sex is outlawed. This means that when men and women are equally situated, they must be treated the same with respect to entitlement to social provision. Yet, [...] men and women are very often not equally situated, especially in that women are far more likely to engage in caregiving that var- iously limits their participation in paid work.

That is, insofar as the male-breadwinner gender order had numerous disadvantages for women, the restructuring of social insurance and assistance programmes according to a dual-earner model is also disadvantageous for women, particularly given that dominant trends are away from full-time, permanent employment and the partial socialisation of social reproduction. Fraser and Gordon (1994: 324) make a similar point, arguing that the ontological privileging of the abstract worker as the universal social subject 'still carries a racial and gender subtext, as it supposes that the worker has access to a job paying a decent wage and is not also a primary parent'. 
Essentially, the privileging of the 'market citizen' and the related processes associated with the reprivatisation of social reproduction have entailed an erasure of the gendered subject of social and economic policies (Brodie 2007; Brodie and Bakker 2008). This trend is not limited to the US, and governments in the UK and Canada are also among those that have most actively worked to restructure social and economic policies in ways that assume the formal equality of citizens despite the persistence of gender-based forms of discrimination in labour markets and the gendered nature of poverty globally. For instance, in Canada, despite the fact that women earn an average of 71 per cent of what men do, certain jurisdictions have eliminated pay equity laws on the basis that they are no longer necessary (Cohen and Cohen 2006).

Fiscal policies, which tend to be presented in mainstream economics and policy-making circles as technical exercises devoid of social content and power relations, are also implicitly framed around the ideal of 'market citizenship' whereby one's well-being is best assured through dependence on the market. However, as feminist political economists have extensively argued, fiscal policies are highly gendered processes, not least in the sense that policies that reduce government revenues (for instance through lower levels of taxation and the privileging of extremely low levels of inflation) have implications for the redistribution of resources between social classes (to the detriment of workers) and between men and women (to the detriment of women) (Çagatay 2003). It will be argued below that the subsidisation of homeownership through the Mortgage Interest Deduction (MID) is a prime example of the gendered nature of fiscal policy.

\section{Debt and the reprivatisation of social reproduction}

The argument that debt has become an increasingly important means of financing social reproduction - or, to put it another way, that debt has been used as a private, market-based form of social policy - has been implicitly made by a small number of critical scholars. For instance, the link between debt and social reproduction is highlighted by Froud et al. (2010) in a study of car loans and credit card debt, which finds that debt has operated as 'a privately led social innovation'. It is further argued that this is underpinned by a discourse that links the extension of credit to the so-called 'democratisation of finance' and the advantages of participation in the 'Ownership Society'. Though they do not focus on the gendered nature of this privately led social innovation, Froud et al. do argue that the extension of credit and asset ownership in an unequal class-based society is an inadequate form of social provisioning since the lower-classes tend to accumulate debt but not assets. As will be argued below, the same can be said for many women and racialised minorities.

A separate but related line of argument is advanced by Leonard Seabrooke (2010) who argues that housing finance is a form of indirect welfare that is shaped by social norms operating in different contexts. According to Seabrooke, while in some countries citizens choose to favour state-based welfare provisioning and are content to rent their homes while receiving better welfare services, in others, citizens choose lower taxes in exchange for an opportunity to store and 
accumulate capital in their homes. Thus, Seabrooke argues that housing finance reflects a 'welfare trade-off' with tax breaks for owner-occupied homes operating as a form of welfare, albeit one that has positive associations and is identified with the norms of entrepreneurship rather than negative forms of dependency (see also Castles 1998; Watson 2008; Schwartz and Seabrooke 2009a; Schwartz and Seabrooke 2009b).

Seabrooke believes that the support for this 'welfare trade-off' and the decision of individuals to enter into subprime mortgage contracts in the US should not be viewed as irrational behaviour but rather as an expression of social wants in accordance with prevailing conventions and norms. It is "rational action based on common knowledge about the need to build assets over a life cycle within the US system' (2010: 56). However, it is necessary to caution that while there is certainly a great deal of popular support for homeownership in the US, conditioned by various fiscal incentives, the ways in which this has played out in the US has ultimately reinforced class-, gender- and race-based divisions and inequalities in wealth and asset ownership.

Indeed, despite the link made in this literature between debt and social provisioning, virtually none of it engages with the decades of feminist political economy and welfare state literature documenting the gender biases that characterise different forms of social provisioning. In so doing, it fails to account for the ways in which the deepening indebtedness among the US population has perpetuated divisions and inequalities in wealth and asset ownership along the lines of gender, as well as those of class and race. Yet, as will be argued below, the retrenchment of socialised forms of provisioning, the privatisation of social housing, the subsidisation of homeownership through the MID tax credit and ultimately, the dramatic growth of subprime lending that has been conditioned by these processes, have all helped to redistribute wealth and social power upward, from the poor to the rich, from women to men and from certain racialised minorities to white men and their families.

The gendered dimensions of social provisioning via debt and mortgage financing are perhaps most clearly articulated in a working paper written by Montgomerie and Young (2011; see also Gill and Roberts 2011; LeBaron and Roberts 2010, 2012). Specifically, Montgomerie and Young argue that in the US, housing finance has operated as a form of 'privatised Keynesianism' (see also Crouch 2009) whereby the wealth contained in one's home has become the primary store of wealth and central to the long-term stability of households. However, they argue that the targeting of single women, and particularly single minority women, for these higher-cost loans, have actually resulted in a (dis)accumulation of wealth and the perpetuation of gender- and race-based inequalities. However, apart from this working paper, there is virtually no academic literature on gender and mortgage debt.

Addressing this glaring gap in the literature, the remainder of this article takes this line of argument forward by outlining some of the ways in which particular embodied subjects have been drawn into financial markets via discriminatory lending practices and in ways that fail to consider the gendered dimensions of paid and unpaid labour. The result of these processes has been the reproduction of social inequalities. At the same time, social reproduction has been rendered 
increasingly insecure as millions of families have lost their homes (and thus their savings) in the wave of foreclosures sweeping the US. Before elaborating these arguments, it is necessary to further document some of the ways in which the deepening of debt, including mortgage-related debt, is related to the reprivatisation of the three overlapping dimensions of social reproduction noted above and to bring into relief the gendered dimensions of this trend.

At the most basic level, the subsidisation of mortgages through the MID tax deduction, the implicit government backing of the GSEs (which played a key role in the purchase and securitisation of mortgages extended to low-income borrowers) and the homeownership campaigns launched by both the Clinton and Bush administrations all operated in ways that promoted the private provisioning of one of the most basic aspects of social reproduction: housing. However, the private provisioning of housing must also be viewed in relation to cuts to social housing that have taken place under neoliberalism. In 2010, the cost of the subsidisation of homeownership through the MID tax credit was an estimated \$108 billion, which is more than double the total outlay ( $\$ 48$ billion) of the Department of Housing and Urban Development (HUD) whose mandate is to improve access to affordable housing and to address discrimination in housing markets.

The attack on social housing was perhaps most virulent under Reagan. Consistent with his broader agenda of dismantling social welfare under the banner of neoliberalism, Reagan presided over much of the period between 1978 and 1988 when the federal budget for social housing fell from $\$ 32$ billion to less than $\$ 10$ billion (in current dollars), amounting to a cut of 80 per cent in real dollars (Wacquant 2009: 52). It was also under Reagan that the Tax Reform Act of 1986 was passed, ushering in new housing programmes that favoured private-sector involvement through a combination of project-based contracts issued to private landlords and housing vouchers that could be used in the private rental market. The Act reduced the tax benefits of investing in rental housing while promoting the private investment in affordable housing development projects through the Low Income Housing Tax Credit (LIHTC) programme, which offers a tax deduction for private investment in affordable housing projects (Dymski 2009: 166). While the LIHTC programme has been found to have increased the number of affordable units available to the poor, subsidising the development of 1.7 million units between 1986 and 2007, it has done little to address the growing cost burden of those who have experienced rising rents, rising utility costs and falling wages (JCHS 2011).

The private provisioning of housing was further promoted through the tenantbased Housing Choice Voucher programme that grew throughout the 1990s and 2000 s to become the largest rental assistance programme in the country. This programme supports the market provisioning of low-cost housing by providing lowincome populations with vouchers that they may use to pay for rent in the private market. However, as with the LIHTC, this programme also fails to tackle rising costs of living, does not compel landlords to offer low-cost housing and does nothing to address the demand for affordable units (JCHS 2011). According to HUD estimates, it is the poorest sectors of society who are most negatively affected by the lack of adequate low-cost housing, with only 36 affordable and available units per 100 'extremely low-income' renter households (HUD 


\section{Adrienne Roberts}

2011a). These processes also disproportionately affect minorities, the elderly, the disabled and single women who rely most heavily on government housing programmes (JCHS 2011: 36).

Insofar as the decline of social housing and the promotion of private forms of housing represents one aspect of the privatisation of social reproduction, the deepening of mortgage debt has also facilitated the off-loading of the costs of social reproduction onto individuals and families who have used it to finance consumption, to pay for education and to meet rising health care costs. Indeed, rather than being used to acquire new assets, an estimated 17 per cent of the home equity extracted in the US - which has increasingly been done through second mortgages, cash-out refinancing loans and home equity lines of credit - has been used to fund consumption while another 20 per cent has been used for personal consumption purposes. Out of the remainder, 19 per cent has been used to finance home improvement while 44 per cent has gone to the acquisition of assets and other uses (Baily et al. 2009: 3).

Credit card debt in the US is also clearly linked to the need to finance social reproduction as credit cards are increasingly being used by the poor and working classes to finance health care in the context of a largely privatised health care system dominated by large insurance companies and rising health care costs. According to one survey, 29 per cent of low- and middle-income households with credit card debt linked their levels of debt to medical expenses. In 2005, the average credit card debt for those carrying medical debt - a sector of the population who have been labelled the 'medically indebted' - was $\$ 14,512$ for those without health insurance and $\$ 10,973$ for those with insurance (Zeldin and Rukavina 2005: 1). Medical indebtedness is then linked to mortgage debt as studies have found that 60 per cent of the 'medically indebted' households that refinanced their homes or took out second mortgages in 2005 used the money to pay down credit cards (2005: 8).

Though it is beyond the scope of this work to explore each of these complex processes in greater detail, the intention is to point to the ways in which debt, including mortgage debt, is being used as a privatised means of financing the three overlapping aspects of social reproduction noted above - namely, forms of biological reproduction, the reproduction and socialisation of the labour force, and the reproduction of provisioning and caring needs. This is a highly gendered process, not least because women continue to take on a disproportionate share of the costs (both in terms of money and time) of social reproduction. Indeed, single-parent households, the vast majority of which are headed by women, are particularly likely to accumulate debt as a means of maintaining standards of living. This is due in large part to the fact that child-care responsibilities tend to reduce earning capacity while simultaneously requiring that incomes be stretched further (Warren 2002). Relatively higher rates of African American single-parent households, ${ }^{3}$ combined with lower incomes and higher rates of poverty among African Americans, have helped to create a situation whereby some of the highest levels of debt are incurred by black single-mother households who carried an average of $\$ 113,000$ in secured debt in 2007, representing a 400 per cent increase from 1992 levels (Montgomerie and Young 2011). 
Given their relatively higher levels of debt, it is also the case that women face higher risks of foreclosure and bankruptcy than other social groups (McGill 2004). Thus, for instance, a recent study found that women's over-representation in health-care related bankruptcies can be attributed to the combined effects of lower incomes, less access to employer-based health insurance, additional costs incurred during child-bearing years, and most importantly, the greater likelihood of having dependent children who also need health care (Jacoby et al. 2001: 396-7). Thus, while mainstream economic discourse materially and discursively obfuscates the gendered dimensions of financial markets, these institutions operate through pre-existing power relations and social hierarchies and condition gender relations in important ways. The following section uses the example of the MID tax deduction in order to point to the ways in which states are implicated in these processes. Whereas the decline of social housing has disproportionately affected the poor and lower classes, women, blacks and Hispanics, the subsidisation of private homeownership through the MID has operated as a highly regressive means of redistributing resources. The MID is also a costly measure, operating as a form of 'fiscal welfare' (Abramovitz 2001) that primarily benefits those who already possess greater amounts of wealth, assets and social power.

\section{MID as social policy}

As one of the oldest and largest federal tax expenditures in the US, the MID is the largest federal subsidy for owner-occupied homes. It is also one of the most regressive forms of taxation in the US, albeit one that is supported by a significant percentage of the population. While the MID has its roots in the Revenue Act of 1913 which allowed for the deduction of personal interest, there is little evidence to suggest that the original motivation for this deduction was to promote homeownership per se (not least because early forms of income taxes were predominantly levied against a small minority of wealthy Americans who were unlikely to finance home purchases). However, given that mortgage debt has historically been the largest portion of consumer debt in the US, the effect of the interest deduction was to encourage homeownership among those sectors of the population who benefited from the deduction (Mann 2000).

While some efforts were made in the 1960s, 1970s and early 1980s to undermine housing tax subsidies, they were never fully repealed and in the 1980s, under the Reagan administration, housing tax subsidies were recoded both legally and discursively, as a central aspect of the American dream and an untouchable aspect of American fiscal policy. To briefly elaborate, in the wake of the fiscal crisis of the early 1980s and in a purported effort to curtail the growing budget deficit, Reagan called for a dramatic revision of the tax code. The resulting Tax Reform Act of 1986 (TRA86) - the same act that promoted private-sector involvement in social housing - eliminated deductions for most forms of consumer interest, including credit card debt and loans to finance cars and other large consumer durables. However, Reagan immunised the MID, calling it 'central to American Values' and a crucial component of 'America's unequivocal commitment to private ownership' (Ventry 2010: 274). TRA86, 
which also preserved the deduction for property taxes, was a significant victory for the housing industry, which considered the preservation of MID its 'biggest issue' and lobbied extensively for its protection. TRA 86 was a victory in the sense that it preserved a controversial 'upside-down subsidy' for private homeownership that was being attacked by certain law-makers and Treasury officials on the basis of its regressive character and high cost to government (the MID was estimated to reduce tax revenues by $\$ 27$ billion in 1986).

TRA86 and subsequent legislation passed the following year further encouraged mortgage debt by capping the amount of debt qualifying for MID at \$1 million on a principle or secondary residence. In addition, new provisions were created for home equity loans that made it easier for borrowers to deduct the interest on loans used to pay for medical or educational expenses. Whereas under the old code, taxpayers had to trace the use of home equity loans, the new home equity provision freed homeowners from that accounting, leading some to argue that the it amounted to 'a house-sized credit card' for consumer purchases (Ventry 2010: 275-6).

The fiscal support of homeownership continued over the subsequent two decades, under both Democratic and Republican administrations. When George W. Bush assembled a tax reform panel in 2005, he reinforced Reagan's immunisation of the MID, cautioning that the deduction should remain untouched. When the panel returned with the recommendation that the MID be transformed into a tax credit (the Home Credit) in order to more equitably distribute the benefits, Bush distanced himself from the panel. So too did various interest groups and members of Congress, including the Democratic House Minority leader at the time, Nancy Pelosi, who argued that the MID was 'untouchable' and that reform would discourage homeownership and stifle economic growth.

The MID has long been one of the costliest government subsidies - or what might be better understood as a form of fiscal welfare - and one that is replicated in few other countries. In 1986, the MID reduced tax revenues by $\$ 27$ billion and 10 years later, this cost doubled to $\$ 57$ billion. The cost more than doubled again over the following 15 years, amounting to around $\$ 108$ billion in 2010 and an estimated $\$ 131$ billion in 2012. These costs exclude additional benefits accrued to homeowners from other tax preferences, such as the deductibility of residential property taxes (estimated to cost $\$ 31$ billion in 2012) and the exclusion of the first $\$ 250,000$ for single and $\$ 500,000$ for joint returns of capital gains on housing (estimated to cost $\$ 50$ billion in 2012) (Toder et al. 2010: 1).

In the wake of the subprime mortgage crisis and the political battles presently being waged in the US Congress over the federal deficit, the MID is receiving some attention from policy-makers, think tanks and certain elements of the mainstream media who are calling for the elimination, or more often, the restructuring, of this costly subsidisation of housing for the wealthiest members of society. However, there is little evidence to suggest that the MID will be considerably revised in the near future and those who have profited from the growth of homeownership in the US have been quick to remind law-makers of the risk of doing so. The National Association of Home Builders, for instance, conducted a survey shortly before the 2010 mid-term election that they claimed found that voters 'overwhelmingly [said] they would be less likely to vote for a candidate for 
Congress who supported either eliminating or reducing the home mortgage interest deduction' (quoted in Wall Street Journal 2010).

Indeed, the subsidisation of private homeownership through MID and other policies has long been supported by a majority of US taxpayers. This is at least partially conditioned by the deliberate framing of homeownership as a right, if not a duty, by various administrations and by the broader promotion of the market as the best and most efficient means of securing one's present and future well-being. As Herman Schwartz (2008) has argued, the promotion of homeownership as a right then tends to promote conservative politics more broadly as rising housing costs create an incentive to prioritise cash income over collective social services and low levels of inflation and low interest rates over government spending.

However, it has been extensively documented that the MID is a highly regressive form of taxation that disproportionately benefits the wealthiest homeowners. For instance, according to one oft-cited analysis, the benefit only applies to the 23.4 per cent of those earning less than $\$ 40,000$ a year who itemise their taxes compared to the 85.5 per cent of those earning between $\$ 75,000$ and $\$ 125,000$ and the 98 per cent of those earning over $\$ 125,000$ who itemise (Poterba and Sinai 2008). According to data provided by the Joint Committee on Taxation, whereas the average MID tax benefit for those earning between $\$ 10,000$ and $\$ 20,000$ a year is $\$ 283$, it rises to $\$ 6649$ for those earning above $\$ 200,000$ a year (Figure 1). The Urban-Brookings Tax Policy Center has further found that

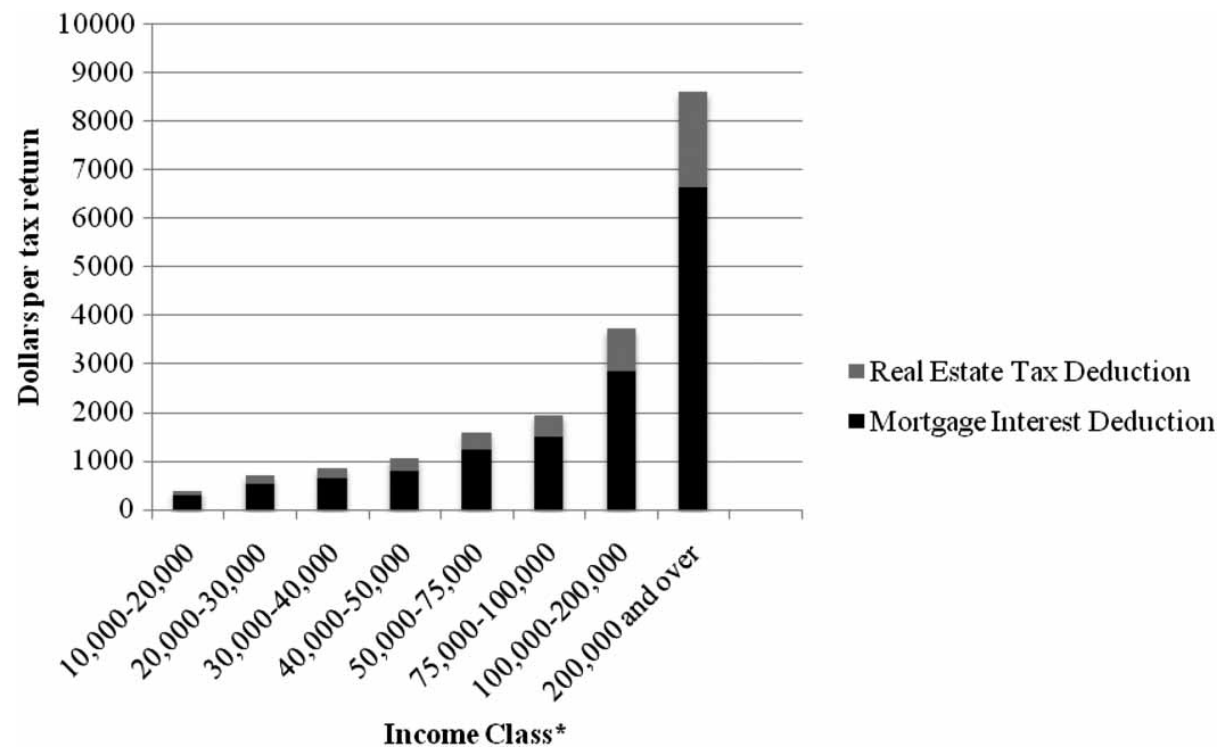

FIGURE 1. Average tax expenditure for mortgage interest and real estate deductions, by income category, fiscal 2009

Source: Joint Committee on Taxation (2010), Estimates of Federal Tax Expenditures for Fiscal Years 2010-2014, JCS-3-10 (Washington), pp. 55-60.

${ }^{*}$ Data not available for those earning below $\$ 10,000$ per year. 
nearly 80 per cent of the benefits from mortgage-interest and property-tax deductions go to the top 20 per cent of taxpayers while 3.5 per cent of the benefits go to the bottom 60 per cent of earners (Timiraos 2009).

Though most of the critiques of the MID focus on its class bias, this deduction is also highly skewed against blacks, Hispanics and women, who have relatively lower incomes, lower rates of homeownership, and lower house values (Toder et. al 2010: 13).

While the government does not disaggregate MID expenditures by gender or race, there is a clear hierarchy in terms of who can actually afford to own their home and thus benefit from the deduction. Homeownership has in this US has been found to be 'most affordable for couples or sharers, then single men, and finally single women, with perhaps one in thirteen of them being able to afford to buy in their own right' (Darke, quoted in Fox 2007-08: 452). Racial inequalities among women are also significant. While 57 per cent of white women owned their homes in 2007, for Hispanic and black women, the percentages were 28 and 33 respectively. The median home value of women of colour also falls far below that of other homeowners. While the average home value of white women was $\$ 74,000$ in 2007 , it was $\$ 47,000$ for black women and $\$ 35,000$ for Hispanic women (Table 1).

The MID is but one of many possible examples of the ways in which fiscal policies channel benefits and encourage property and asset accumulation differentially by gender and race. Other examples include tax provisions pertaining to inheritance, capital gains taxes, pension provisions, child care credits and so on. Ultimately, while these policies are underpinned by a discourse of equal opportunity and purport to be gender- and race-blind, in practice, they tend to reflect and

TABLE 1. Asset ownership by household type and race, ages 18-64, 2007

\begin{tabular}{|c|c|c|c|c|c|c|}
\hline & \multicolumn{2}{|c|}{ Cash Accounts } & \multicolumn{2}{|c|}{ Home } & \multicolumn{2}{|c|}{ Stock } \\
\hline & $\begin{array}{c}\% \text { who } \\
\text { own }\end{array}$ & $\begin{array}{c}\text { Median } \\
\text { value }\end{array}$ & $\begin{array}{c}\% \text { who } \\
\text { own }\end{array}$ & $\begin{array}{c}\text { Median } \\
\text { value }\end{array}$ & $\begin{array}{c}\% \text { who } \\
\text { own }\end{array}$ & $\begin{array}{c}\text { Median } \\
\text { value }\end{array}$ \\
\hline \multicolumn{7}{|l|}{ White } \\
\hline Married/cohabiting & 97 & $\$ 7,100$ & 82 & $\$ 104,000$ & 67 & $\$ 45,000$ \\
\hline Single male & 91 & $\$ 3,400$ & 50 & $\$ 70,000$ & 51 & $\$ 25,400$ \\
\hline Single female & 92 & $\$ 1,900$ & 57 & $\$ 74,000$ & 45 & $\$ 18,625$ \\
\hline \multicolumn{7}{|l|}{ Black } \\
\hline Married/cohabiting & 86 & $\$ 2,000$ & 59 & $\$ 54,000$ & 48 & $\$ 18,200$ \\
\hline Single male & 72 & $\$ 2,200$ & 39 & $\$ 63,000$ & 26 & $\$ 12,750$ \\
\hline Single female & 77 & $\$ 1,180$ & 33 & $\$ 47,000$ & 23 & $\$ 15,300$ \\
\hline \multicolumn{7}{|l|}{ Hispanic } \\
\hline Married/cohabiting & 85 & $\$ 2,600$ & 57 & $\$ 92,000$ & 28 & $\$ 14,100$ \\
\hline Single male & 62 & $\$ 2,500$ & 29 & $\$ 93,000$ & 23 & $\mathrm{n} / \mathrm{a}$ \\
\hline Single female & 67 & $\$ 650$ & 28 & $\$ 35,000$ & 14 & $\mathrm{n} / \mathrm{a}$ \\
\hline
\end{tabular}

Source: Insight Center for Community Economic Development (2010), Lifting as We Climb: Women of Color, Wealth, and America's Future (Oakland, CA). 
reify existing resource allocations in ways that privilege the white heteronormative nuclear family (Bakker 1994b; see also Young et al. 2011). The unequal distribution of wealth cannot be separated from a much longer history of gender and racial inequality that will not be recounted here. However, the more immediate point has been to suggest that fiscal policies such as the MID have created and sustained existing patterns of wealth inequality and have extended them to future generations (Shapiro and Oliver 1995: 284).

\section{The role of class, gender and race in determining access to credit}

Insofar as the MID and a range of additional fiscal and monetary policies draw upon and reproduce inequalities as a result of the erasure of embodied and socially embedded subjects, it is also the case that more direct forms of sexism and racism play a role in conditioning one's relation to financial markets. Indeed, this discrimination has been well documented in several recent studies on subprime lending that demonstrate that the historical exclusion of women, racialised minorities and the working poor from access to credit has been replaced by their integration on inequitable and often predatory terms. In the process, the social reproduction of generations of people has been rendered increasingly precarious and insecure.

There are clearly progressive aspects to the elimination of discrimination in credit markets, which has been a site of social struggle for decades. For instance, during and after the Civil Rights era, the fight against redlining and other forms of discrimination in credit markets was a central focus of many black social movements (Dymski 2009; Seabrooke 2010). Women's groups, liberal and radical in orientation, also rallied around the goal of the elimination of discrimination in credit markets. Among their main concerns were: the much harder time that single women had accessing credit than single men; the inability for many married women to receive credit in their own name; and the difficulty of divorced or widowed women in re-establishing credit. While the 1974 Equal Credit Opportunity Act and subsequent legislation officially banned discrimination, as the proliferation of subprime lending in the US clearly demonstrates, discrimination continues to pervade credit markets and to create the basis for differential integration into the Ownership Society.

While some would argue that the higher cost of subprime loans (estimated to amount to between $\$ 85,000$ and $\$ 186,000$ more in interest than average loans (Fishbein and Woodall 2006a: 3) reflects the higher risk associated with these borrowers, it has been found that over half of these loans were given to individuals with credit scores high enough to merit conventional loans (Dymski 2009: 171-72). This has immediate implications for the social reproduction of the millions of Americans who have lost their homes and savings in the foreclosure crisis. At the same time, there are also longer-term implications for social mobility as the foreclosure crisis has precluded the possibility of using home equity to pay for higher education, supplement retirement savings, etc., or to rely on it as a safety net of last resort in cases of illness, job loss, etc. (Bocian et al. 2010: 4).

In recent years, there has been a proliferation of studies documenting the ways in which women and certain racialised minorities were explicitly targeted for 
subprime lending and are subsequently disproportionately represented among those who have been dispossessed from their homes and their wealth (Fishbein and Woodall, 2006a; Gruenstein et al. 2006; Morris 2009; Wyly et al. 2006). For instance, it has been found that even when income and credit risk are equal, African Americans are up to 34 per cent more likely to receive higher-rate and subprime loans than their white counterparts and that subprime lending is five times more prevalent in African American neighbourhoods than in white neighbourhoods (Morris 2009: 2-3).

Despite the equalising discourse of market citizenship, largely as a result of the foreclosure crisis, the gap in home ownership between black and white Americans is the widest it has been since records began 16 years ago (Braithwaite 2011). While the majority of those families who lost their homes in the first three years of the foreclosure crisis were non-Hispanic and white, African American and Latino families were disproportionately affected relative to their share of mortgage originations (Table 2). As with lending patterns more broadly, the racial and ethnic disparities in foreclosures are present even after controlling for differences in income patterns between demographic groups.

While subprime mortgages generated large amounts of money for many lenders (who generated an estimated $\$ 100$ billion in annual revenues in the mid-2000s) and speculators, this accumulation has been based on the widespread dispossession of the lower classes, women and racialised minorities from their homes and wealth (Strauss 2009). As is evidenced in a recent Pew study, the loss of home equity combined with rising levels of unsecured debt in the wake of the housing collapse has significantly increased class- and race-based inequalities in wealth. According to the study, Hispanic households fared the worst as their average net worth fell 66 per cent between 2005 and 2009, from $\$ 18,359$ to $\$ 6,325$. The net worth of black households dropped 53 per cent during this period, from $\$ 12,124$ to $\$ 5,677$ and white households lost 16 per cent of their net worth which declined from $\$ 134,992$ to $\$ 113,149$ (Taylor et al. 2011: 5).

TABLE 2. 2007-09 Foreclosures of recent first-lien owner-occupied mortgage originations (200508 ) by race and ethnicity

\begin{tabular}{lcccc}
\hline Borrow group & $\begin{array}{c}\text { Share of } \\
\text { originations }\end{array}$ & $\begin{array}{c}\text { Completed } \\
\text { foreclosure rate }\end{array}$ & $\begin{array}{c}\text { Share of } \\
\text { completed } \\
\text { foreclosures }\end{array}$ & $\begin{array}{c}\text { Disparity } \\
\text { ratio }\end{array}$ \\
\hline Non-Hispanic White & $65.9 \%$ & $4.5 \%$ & $56.1 \%$ & 1.00 \\
African American & $7.8 \%$ & $7.9 \%$ & $11.6 \%$ & 1.76 \\
Latino & $11.2 \%$ & $7.7 \%$ & $16.2 \%$ & 1.71 \\
Asian & $3.9 \%$ & $4.6 \%$ & $3.3 \%$ & 1.02 \\
American Indian & $0.4 \%$ & $5.9 \%$ & $0.4 \%$ & 1.31 \\
Hawaiian/Pacific Islander & $0.4 \%$ & $6.3 \%$ & $0.5 \%$ & 1.40 \\
Other & $10.5 \%$ & $6.0 \%$ & $11.8 \%$ & 1.33 \\
Total & $100.0 \%$ & $5.3 \%$ & $100.0 \%$ & 1.18 \\
\hline
\end{tabular}

Source: Bocian, D.G., Li, W. and Ernst, K.S. (2010), Foreclosures by Race and Ethnicity: The Demographics of a Crisis (Center for Responsible Lending), p. 8. 
While the wealthiest 10 per cent of households within each group faced some loss of wealth during this period, their share of the group's overall wealth rose. Specifically, the top 10 per cent of Hispanic households increased their share of Hispanic wealth from 56 per cent in 2005 to 72 per cent in 2009. For black households, the share increased from 59 per cent to 67 per cent and for white households, this number rose from 46 per cent to 51 per cent (Taylor et al. 2011: 32). Thus, the predatory integration of the lower classes, racialised minorities and women into mortgage finance has intensified inequalities across US society.

As critical geographers and others have argued, there are also important spatial dimensions to subprime lending and the subsequent foreclosure and economic crises as it is not just individual homeowners and families, but rather entire communities that have been affected by predatory lending practices. ${ }^{4}$ For instance, it has been estimated that the depreciation of home values caused by foreclosures will destroy $\$ 1.86$ trillion in the home value of surrounding property owners (Bocian et al. 2010: 4). Communities with high concentrations of foreclosures, which are disproportionately African-American and Latino communities, will further lose much needed tax revenue and incur the long-term costs of abandoned homes and 'neighbourhood blight' (Bocian et al. 2010: 4; Bowdler et al. 2010). It has been estimated that African Americans and other people of colour are at risk of losing an estimated $\$ 164$ billion of wealth as a result of discriminatory lending practices (Rivera et al. 2008; Morris 2009). As one author has put it "for black America, the "mortgage meltdown" looks less like a market hiccup than a massive strip mining of hard-won wealth, a devastating loss that will betray the promise of class mobility for tens of thousands of black families' (Wright 2008).

In a similar manner, as growing numbers of women have bought their homes, this has not equalised wealth as the targeting of women for subprime loans has prevented them from using their homes as wealth-building assets to the same extent as men with similar levels of income. Whereas 29 per cent of men with debt to income ratios that were smaller than the national average received subprime loans in 2006, this was the case for 38 per cent of women (Ginty 2010). According to other estimates, while women make up 30 per cent of borrowers for all mortgages, they make up 38.8 per cent of subprime borrowers, bringing the rate of over-representation to 29.1 per cent.

The persistence of gender-based wage gaps and the ongoing feminisation of poverty in the US do not fully account for this differential as gender disparities in all mortgage products (including home purchase, refinance and home improvement loans) exist across all income levels and actually increase as levels of income rise. Whereas women earning below the median income are 3.3 per cent more likely to receive subprime mortgages than men with similar incomes, women who earn double the median income are almost 50 per cent more likely to receive such mortgages than men (Fishbein and Woodall 2006b: 3-4). Foreclosure and the loss of home equity in the face of falling housing prices also have particular gendered dimensions since women - while having less assets overall than men - tend to have their assets concentrated in home equity far more often than men (Ginty 2010). 
Considering the intersectionality of class-, gender- and race-based forms of discrimination, it is perhaps unsurprising that women of colour face some of the highest levels of discrimination and have the highest rates of subprime borrowing. For instance, whereas an African American woman is 5.7 per cent more likely to receive a subprime mortgage than an African American man, she is 256.1 per cent more likely to receive one than a white man. Again, this disparity is not linked directly to income levels, but rather exists at every level of income and grows as income rises: an African American woman earning more than twice the median income is nearly five times more likely to receive a subprime mortgage than a white man with a similar income (Fishbein and Woodall, 2006b: 3-4).

The gendered relations of social reproduction also play an important role in conditioning the discrimination against women in credit markets. For example HUD is currently involved in a number of lawsuits against mortgage lenders who have been found to have denied loans to pregnant women and women on pregnancy-related leave. Despite laws that prohibit discrimination based on sex or familial status (including pregnancy or children in the family), some lenders have linked pregnancy to lower incomes and work interruptions, deeming these women to be higher risk borrowers (HUD 2011b). Thus, while the MID tax credit and many trends associated with the reprivatisation of social reproduction more broadly have reproduced inequalities through the erasure of the gendered subject and with it, the erasure of inequalities in paid and unpaid labour and the distribution of material resources, in other ways, discrimination based on sex and race continues to pervade so-called objective market relations. So too do particular gendered assumptions regarding the determination of one's creditworthiness or 'riskiness' (cf. Langley 2008, Aitken, 2010).

\section{Concluding reflections}

As feminist IPE scholars have been arguing for the past several decades, gender does not simply operate alongside markets but is rather constitutive of markets and the reproduction of the social relations of capitalism more broadly (Bakker 1994a; Elson and Cagatay 2000; Marchand and Runyan 2000; Young et al. 2011). In order to take this line of argument forward, it is necessary to further demystify the idea that financial markets operate as abstract and disembedded institutions and to develop feminist IPE frameworks that consider the interplay of the relations of power, production and social reproduction in shaping the international political economy.

It is also necessary to develop alternative ways of addressing the crisis of social reproduction that is being experienced by much of the global population, including certain segments within the US population. The contradictions of the state-led strategy of financing social reproduction through debt have been become apparent at the individual level as well as at the level of the international political economy (evidenced by the global financial crisis and the ongoing fiscal crises of many governments, including in the US and the European Union). One way forward proposed by feminists involves creating gender budget initiatives that analyse the differential impacts of the allocation of government funds (such as through the 
MID) on women and men, boys and girls. These analyses can then be used to formulate more equitable budgets and to facilitate the ability of equity seeking groups to make claims on public resources (Cagatay 2003; Elson 2004). In disaggregating the costs of neoliberal social and economic policies, such an approach is important in addressing current inequalities. It is also important in challenging the reconsolidation of class and gender-based power in the wake of the crisis that seems to be taking place through massive cuts to social spending for the most needy without any significant new financial regulation or tax increases for corporations or the wealthiest sectors of the population.

\section{Notes}

1. Earlier versions of this article were presented at the 2011 International Studies Association Annual Convention, at the VU University Amsterdam and at the Irmgard Coninx Foundation $14^{\text {th }}$ Berlin Roundtables on Transnationality, Financialization and Everyday Life. I thank all of the participants in these events who offered helpful comments and criticisms of this article as well as three anonymous reviewers. I would also like to thank Isabella Bakker and Susanne Soederberg for helping to shape the article and the Social Sciences and Humanities Research Council and Queen's University for providing funding for this project.

2. For example, the Personal Responsibility and Work Opportunity Reconciliation Act (PRWORA), signed into law by Bill Clinton in 1996 as part of his campaign promise to 'end welfare as we know it', shifted some of the responsibilities of immigration and crime control agencies onto welfare agencies, requiring those that administer welfare block grants, SSI and housing assistance to determine the immigration status of clients before providing services. It has been estimated that this will cost welfare agencies an additional $\$ 700$ million, draining already diminished resources. States have also increasingly been compelling welfare recipients to submit to drug testing. In 2009, over half of all states introduced drug testing legislation which, in addition to perpetuating the social construction of the poor as deviant and 'undeserving', uses resources that could otherwise be used to assist the poor in a time of economic struggle (Bohrman and Murakawa 2005; Budd 2011).

3. According to 2009 Census Bureau data, nearly one-quarter of all children under the age of 18 lives in a singlemother family. This is the case for around 16 per cent of white children, 27 per cent of Latino children and 52 per cent of African American children.

4. Though this literature cannot be fully surveyed here, some important contributions include Holloway (1998), Holloway and Wyly (2001), Howell (2006), Wyly et al. (2006) and Dymski (2008).

\section{Notes on contributor}

Adrienne Roberts is a SSHRC Post-Doctoral Research Fellow in the Department of Political Studies, Queen's University, Kingston, Ontario. Her recent publications appear in Politics \& Gender, Signs and Antipode.

\section{References}

Abramovitz, M. (2001), 'Everyone is Still on Welfare: The Role of Redistribution in Social Policy', Social Work, 46 (4), pp. 297-309.

Aitken, R. (2010), 'Regul(ariz)ation of Fringe Credit: Payday Lending and the Borders of Global Financial Practice', Competititon and Change, 14 (2), pp. 80-99.

Austin, R. (2004), 'Of Predatory Lending and the Democratization of Credit: Preserving the Social Safety Net of Informality in Small-Loan Transactions', American University Law Review, 53, pp. 1217-57.

Baily, M., Lund, S. and Atkins, C. (2009), Will US Consumer Debt Reduction Cripple the Recovery? (McKinsey Global Institute).

Bakker, I. (ed.) (1994a), The Strategic Silence: Gender and Economic Policy (London: Zed Books).

Bakker, I. (1994b), 'Introduction: Engendering Macro-economic Policy Reform in the Era of Global Restructuring and Adjustment', in I. Bakker (ed.) The Strategic Silence: Gender and Economic Policy (Ottawa: Zed Books), pp. 1-22. 


\section{Adrienne Roberts}

Bakker, I. (2003), 'Neoliberal Governance and the Reprivatisation of Social Reproduction', in I. Bakker and S. Gill (eds), Power, Production, and Social Reproduction (New York: Palgrave Macmillan), pp. 66-82.

Bakker, I. (2007), 'Social Reproduction and the Constitution of a Gendered Political Economy', New Political Economy, 12 (4), pp. 541-56.

Bakker, I. and Gill, S. (eds) (2003), Power, Production, and Social Reproduction (New York: Palgrave Macmillan).

Bezanson, K. and Luxton, M. (eds) (2006), Social Reproduction: Feminist Political Economy Challenges NeoLiberalism (Montreal and Kingston: McGill-Queen's University Press).

Bocian, D.G., Li, W. and Ernst, K.S. (2010), Foreclosures by Race and Ethnicity: The Demographics of a Crisis, (Durham NC: Center for Responsible Lending).

Bohrman, R. and Murakawa, N. (2005), 'Remaking Big Government: Immigration and Crime Control in the United States', in J. Sudbury (ed.) Global Lockdown: Race, Gender, and the Prison-Industrial Complex (New York: Routledge), pp. 109-26.

Braithwaite, T. (2011), 'US Homeowners Racial Gap Widens', Financial Times, 16 February.

Brodie, J. (2007), 'Canada's Three Ds: The Rise and Decline of the Gender-based Policy Capacity', in M.G. Cohen and J. Brodie (eds), Remapping Gender in the New Global Order (New York: Routledge), pp. 166-84.

Brodie, J. and Bakker, I. (2008), Where are the Women? Gender Equity, Budgets and Canadian Public Policy (Ottawa: Canadian Centre for Policy Alternatives).

Budd, J.C. (2011), 'Pledge Your Body for Your Bread: Welfare, Drug Testing, and the Inferior Fourth Amendment', William and Mary Bill of Rights Journal, 19 (3), pp. 751-804.

Çagatay, N. (2003), 'Gender Budgets and Beyond: Feminist Fiscal Policy in the Context of Globalization', Gender and Development, 11 (1), pp. 15-24.

Castles, F.G. (1998), 'The Really Big Trade-off: Home Ownership and the Welfare State in the New World and the Old', Acta Politica, 33 (1), pp. 5-19.

CRL (2007), 'Subprime Lending: A Net Drain on Homeownership', CRL Issue Paper No. 14 (Durham NC: Center for Responsible Lending) 27 March.

Cohen, M.G. and Cohen, M. (2006), 'Privatization: A Strategy for Eliminating Pay Equity in Health Care', in K. Bezanson and M. Luxton (eds), Social Reproduction: Feminist Political Economy Challenges NeoLiberalism (Montreal and Kingston: McGill-Queen's University Press), pp. 117-44.

Crouch, C. (2009), 'Privatised Keynesianism: An Unacknowledged Policy Regime', British Journal of Politics and International Relations, 11 (2), pp. 382-99.

Dymski, G.A. (2009), 'Racial Exclusion and the Political Economy of the Subprime Crisis', Historical Materialism, 17, pp. 149-79.

Elson, D. (2004), 'Engendering Government Budgets in the Context of Globalization(s)', International Feminist Journal of Politics, 6 (4), pp. 623-42.

Elson, D. and Çagatay, N. (2000), 'The Social Content of Macroeconomic Policies', World Development, 28 (7), pp. 1347-64.

Fishbein, A.J. and Woodall, P. (2006a), Subprime Locations: Patterns of Geographic Disparity in Subprime Lending (Washington, DC: The Consumer Federation of America).

Fishbein, A.J. and Woodall, P. (2006b), Women are Prime Targets for Subprime Lending: Women are Disproportionately Represented in High-Cost Mortgage Market (Washington, DC: The Consumer Federation of America).

Folbre, N. and Nelson, J.A. (2000), 'For Love or Money - Or Both?' Journal of Economic Perspectives, 12 (2), pp. $123-40$.

Fox, L. (2007-08), 'Re-Possessing "Home": A Re-Analysis of Gender Homeownership and Debtor Default for Feminist Legal Theory', William and Mary Journal of Women and the Law, 14, pp. 423-94.

Fraser, N. (1994), 'After the Family Wage: Gender Equity and the Welfare State', Political Theory, 22 (4), pp. 591-618.

Froud, J., Sukhdev, J., Montgomerie, J. and Williams, K. (2010), 'Escaping the Tyranny of Earned Income? The Failure of Finance as Social Innovation', New Political Economy, 15 (1), pp. 147-64.

Gill, S. and Roberts, A. (2011), 'Macroeconomic Governance, Gendered Inequality and Global Crises', in B. Young, I. Bakker and D. Elson (eds), Questioning Financial Governance from a Feminist Perspective (London and New York: Routledge), pp. 154-71. 
Ginty, M. (2010), 'In Subprime Fallout, Women Take a Heavy Hit', womensenews.org, 14 January. Available from: http://womensenews.org/story/economyeconomic-policy/100113/in-subprime-fallout-women-takeheavy-hit [accessed 12 August 2011].

Gruenstein, D.B., Ernst, K.S. and Li, W. (2006), Unfair Lending: The Effects of Ethnicity on the Price of Subprime Mortgages (Durham NC: Centre for Responsible Lending).

Harvey, D. (2010), The Enigma of Capital and the Crises of Capitalism (New York: Oxford University Press).

Hatzius, J. and Marschoun, M.A. (2009), Home Prices and Credit Losses: Projections and Policy Options, (Goldman Sachs Global Economics Paper).

Holloway, S.R. (1998), 'Exploring the Neighborhood Contingency of Race Discrimination in Mortgage Lending in Columbus, Ohio', Annals of the Association of American Geographers, 88 (2), pp. 252-76.

Holloway, S.R. and Wyly, E.K. (2001), 'The Color of Money Expanded: Geographically Contingent Mortgage Lending in Atlanta, Georgia', Journal of Housing Research, 12 (1), pp. 55-90.

Howell, B. (2006), 'Exploiting Race and Space: Concentrated Subprime Lending as Housing Discrimination', California Law Review, 94, pp. 101-47.

HUD (2011a), Evidence Matters: Transforming Knowledge into Housing and Community Development Policy (US Department of Housing and Urban Development).

HUD (2011b), HUD Acts Against Pregnancy Discrimination in Home Mortgages, Press Release No. 11-109 (Department of Housing and Urban Development).

ILO (2009), Gender Equality at the Heart of Decent Work (Geneva: International Labour Organization).

ILO (2010), Women in Labour Markets: Measuring Progress and Identifying Challenges (Geneva: International Labour Organization).

Jacoby, M.B., Sullivan, T.A. and Warren, E. (2001), 'Rethinking the Debates Over Health Care Financing: Evidence from the Bankruptcy Courts', New York University Law Review, 76 (2), pp. 375-418.

JCHS (2011), America's Rental Housing: Meeting Challenges, Building on Opportunities (Joint Center for Housing Studies of Harvard University) [online] Available from: http://www.jchs.harvard.edu/ publications/rental/rh11_americas_rental_housing/index.html [accessed 20 May 2011].

Klein, N. (2008), 'Disowned by the Ownership Society', The Nation, 18 February.

Langley, P. (2008), 'Sub-Prime Mortgage Lending: A Cultural Economy', Economy and Society, 37 (4), pp. 469-94.

LeBaron, G. (2010), 'The Political Economy of the Houshold: Neoliberal Restructuring, Enclosures, and Daily Life', Review of International Political Economy, 17 (5), pp. 889-912.

LeBaron, G. and Roberts, A. (2010), 'Toward a Feminist Political Economy of Capitalism and Carcerality', Signs, 36 (1), pp. 19-44.

LeBaron, G. and Roberts, A. (2012), 'Confining Social Insecurity: Debt, Prison and the Rise of the Neoliberal Debtors' Prison', Politics \& Gender, March.

Mann, R.F. (2000), 'The (Not So) Little House on the Prairie: The Hidden Costs of the Home Mortgage Interest Deduction', Arizona State Law Journal, 32, pp. 1347-400.

Marchand, M. and Runyan, A.S. (eds) (2000), Gender and Global Restructuring: Sightings, Sites and Resistances (London and New York: Routledge).

McGill, Y. (2004), The Debt Trap of Payday Lending: Protect Economic Security for Women and Families, Issue Brief No. 19 (Durham NC: Center for Responsible Lending).

McNally, D. (2011), Global Slump: The Economics and Politics of Crisis and Resistance (Winnipeg: Fernwood Publishing).

Montgomerie, J. and Young, B. (2011), 'Home is Where the Hardship is: Gender and Wealth (Dis)Accumulation in the Subprime Boom', CRESC Working Paper Series, Working Paper No. 79.

Morris, M. (2009), Discrimination and Mortgage Lending in America: A Summary of the Disparate Impace of Subprime Mortgage Lending on African Americans (Baltimore: NAACP).

Orloff, A. (2002), Women's Employment and Welfare Regimes: Globalization, Export-Oriented and Social Policy in Europe and North America (New York: United Nations Research Institute for Social Development).

Panitch, L. and Konings, M. (eds) (2009), American Empire and the Political Economy of Global Finance (Basingstoke and New York: Palgrave Macmillan).

Poterba, J. and Sinai, T. (2008), 'Tax Expenditures for Owner-Occupied Housing: Deductions for Property Taxes and Mortgage Interest and the Exclusion of Imputed Rental Income', American Economic Review, 98 (2), pp. 84-9. 


\section{Adrienne Roberts}

Rivera, A., Cotto-Escalara, B., Desai, A., Huezo, J. and Muhammad, D. (2008), Foreclosed: State of the Dream (Boston: United for a Fair Economy).

Sassen, S. (2008), 'Mortgage Capital and Its Particularities: A New Frontier for Global Finance', Journal of International Affairs, 62 (1), pp. 187-212.

Sassen, S. (2010), 'A Savage Sorting of Winners and Losers: Contemporary Versions of Primitive Accumulation', Globalizations, 7 (1-2), pp. 33-50.

Schwartz, H. (2008), 'Housing, Global Finance, and American Hegemony: Building Conservative Politics One Brick at a Time', Comparative European Politics, 6, pp. 262-84.

Schwartz, H. (2009), Subprime Nation: American Power, Global Capital, and the Housing Bubble (Ithaca, NY: Cornell University Press).

Schwartz, H. and Seabrooke, L. (eds) (2009a), The Politics of Housing Booms and Busts (Basingstoke: Palgrave Macmillan).

Schwartz, H. and Seabrooke, L. (2009b), 'Varieties of Residential Capitalism in the International Political Economy: Old Welfare States and the New Politics of Housing', in H. Schwartz and L. Seabrooke (eds), The Politics of Housing Booms and Busts (Basingstoke: Palgrave Macmillan), pp. 1-27.

Seabrooke, L. (2010), 'What Do I Get? The Everyday Politics of Expectations and the Subprime Crisis', New Political Economy, 15 (1), pp. 51-70.

Shapiro, T. and Oliver, M. (1995), Black Wealth/White Wealth: A New Perspective on Racial Inequality (New York: Routledge).

Soederberg, S. (2007), 'Freedom, Ownership, and Social (In-)Security in the United States', Cultural Critique, 65, pp. 94-114.

Strauss, K. (2009), 'Accumulation and Dispossession: Lifting the Veil on the Subprime Mortgage Crisis', Antipode, 14 (1), pp. 10-14.

Taylor, P., Kochhar, R., Fry, R., Velasco, G., and Motel, S. (2011), Twenty-to-One: Wealth Gap Rises to Record Highs Between Whites, Blacks and Hispanics (Washington: Pew Research Center).

Toder, E., Turner, M., Lim, K. and Getsinger, L. (2010), Reforming the Mortgage Interest Deduction (Urban Institute, Tax Policy Center and What Works Collaborative). 1.

Timiraos, N. (2009), 'Mortgage Deduction Looks Less Sacred', Wall Street Journal, 27 February

Ventry, Jr., D.J. (2010), 'The Accidental Deduction: A History and Critique of the Tax Subsidy for Mortgage Interest', Law and Contemporary Problems, 73 (1), pp. 233-86.

Wacquant, L. (2009), Punishing the Poor: The Neoliberal Government of Social Insecurity (Durham NC and London: Duke University Press).

Wall Street Journal (2010), 'Big Shock: Americans Like the Mortgage Interest Deduction', 22 September.

Warren, E. (2002), 'What is a Women's Issue? Bankruptcy, Commercial Law, and Other Gender-Neutral Topics', Harvard Women's Law Journal, 25, pp. 1-39.

Watson, M. (2008), 'Constituting Monetary Conservatives via the "Savings Habit": New Labour and the British Housing Market Bubble', Comparative European Politics, 6 (3), pp. 285-304.

Wigan, D. (2010), 'Credit Risk Transfer and Crunches: Global Finance Victorious or Vanquished?' New Political Economy, 15 (1), pp. 109-25.

Wright, K. (2008), 'The Sub-Prime Swindle', The Nation, 26 June.

Wyly, E.K., Attia, M., Foxcroft, H., Hammel, D. and Phillips-Watts, K. (2006), 'American Home: Predatory Mortgage Capital and Neighbourhood Spaces of Race and Class Exploitation in the United States', Geografiska Annaler Series B - Human Geography, 88 (1), pp. 105-32.

Young, B. (2001), 'The "Mistress" and the "Maid" in the Globalized Political Economy', in L. Panitch and C. Leys (eds), Working Classes: Global Realities Socialist Register 2001 (London: Merlin Press), pp. 264-76.

Young, B., Bakker, I. and Elson, D. (eds) (2011), Questioning Financial Governance from a Feminist Perspective (London, New York: Routledge).

Zeldin, C. and Rukavina, M. (2005), Borrowing to Stay Healthy: How Credit Card Debt is Related to Medical Expenses (New York: Demos). 